\title{
Jeruk Sebagai Media Pembelajaran untuk Mengetahui Pengaruh Tingkat Keasaman (pH) terhadap Waktu Polarisasi pada Elemen Volta
}

\author{
Yudi Setyawati \\ SMP Negeri 3 Selomerto, Wonosobo, Jawa Tengah \\ Desa Adiwarno, Selomerto, Wonosobo, Jawa Tengah \\ Kholid Yusuf \\ SMP Negeri I Garung, Wonosobo, Jawa Tengah \\ J1. Raya Dieng Km 09, Garung, Wonosobo, Jawa Tengah \\ Surat-e: DiesmaI9@yahoo.co.id
}

Fokus pembelajaran yang bermakna adalah mengkonstruksikan pengetahuan yang didalamnya siswa berusaha memahami materi sesuai apa yang mereka alami. Kegiatan di dalam laboratorium merupakan salah satu pembelajaran yang melibatkan peserta didik terlibat aktif membuktikan suatu konsep fisika

Salah satu materi pada kelas IX adalah elemen volta. Elemen volta tidak dapat menghantarkan arus listrik dalam waktu yang lama karena terjadinya polarisasi. Untuk membuat pembelajaran menarik, diperlukan media yang manyenangkan dan menantang, media digunakan untuk menguji kadar $\mathrm{pH}$ dengan proses polarisasi. Larutan elektrolit yang digunakan adalah ekstrak jeruk yang dikondisikan dengan $\mathrm{pH}$ berbeda, buah jeruk dipilih sebagai larutan elektrolit karena bersifat asam, mudah di dapat dan murah. Elektrodanya lempeng $\mathrm{Cu}$ sebagai kutub positif dan lempeng $\mathrm{Zn}$ sebagai kutub negatif. Dari hasil kegiatan diperoleh data, semakin rendah nilai $\mathrm{pH}$ larutan (semakin asam) proses polarisasi terjadi lebih lama dibandingkan ekstrak jeruk yang memiliki nilai $\mathrm{pH}$ lebih tinggi (kurang asam).

Kata kunci: jeruk, media pembelajaran, tingkat keasaman $(\mathrm{pH})$, polarisasi, elemen volta

\section{Pendahuluan}

Pembelajaran bermakna adalah mengkonstruksikan pengetahuan dimana siswa berusaha memahami materi sesuai apa yang mereka alami. Konsep, hukum, dan pesamaan dalam fisika akan lebih tertanam kuat didalam ingatan peserta didik jika mereka mengalami langsung untuk membuktikan konsep tersebut.

Penggunaan media pembelajaran yang tepat merupakan salah satu proses pembelajaran yang dapat melibatkan peserta didik ikut terlibat aktif membuktikan suatu konsep fisika. Pada materi kelas IX tentang sumber arus listrik, menyebutkan bahwa salah satu sumber tegangan primer adalah elemen volta. Elemen volta merupakan sebuah elemen yang tersusun atas tembaga $(\mathrm{Cu})$ sebagai kutub positif, seng $(\mathrm{Zn})$ sebagai kutub negatif dan asam sulfat $\left(\mathrm{H}_{2} \mathrm{SO}_{4}\right)$ sebagai larutan elektrolitnya. Kelemahan dari elemen volta adalah tidak mampu menghantarkan arus listrik dalam jangka waktu yang lama karena terjadi proses polarisasi.
Larutan elektrolit yang berupa asam sulfat memiliki $\mathrm{pH}$ dibawah 7 (asam), sifat asam pada asam sulfat sebagai larutan elektrolit dapat digantikan dengan larutan lain yang sama-sama bersifat asam. Untuk mendekatkan peserta didik dengan lingkungan dan menambah wawasan mereka maka larutan elektronit yang digunakan sebagai media adalah asam yang berasal dari buah-buahan. Buah yang dipilih adalah jeruk yang mengandung asam sitrat $\left(\mathrm{C}_{6} \mathrm{H}_{8} \mathrm{O}_{7}\right)$.

Penulis ingin menyumbangkan pemikirannya untuk memanfaatkan media pembelajan yang ada di sekitar sekaligus membuat pembelajaran menjadi lebih bermakna bagi peserta didik. Materi pada kegiatan eksperimen dikembangkan dengan menyelidiki pengaruh tingkat keasaman buah jeruk $(\mathrm{pH})$ dengan waktu polarisasi. Indikator waktu polarisasi ditunjukkan dengan lamanya arus mengalir pada rangkaian. 


\section{Kajian Pustaka}

Proses pembelajaran merupakan proses komunikasi dan berlangsung dalam suatu sistem, maka media pembelajaran menempati posisi yang cukup penting sebagai salah satu komponen sistem pembelajaran. Tanpa media, komunikasi tidak akan terjadi dan proses pembelajaraan sebagai proses komunikasi juga tidak akan berlangsung secara optimal.[I][2] Dengan adanya media materi yang disampaikan akan lebih mudah diterima oleh peserta didik, karena mereka dapat menangkap konsep yang ada tidak hanya sebatas abstrak tetapi mereka dapat mengamati secara langsung.

Daryanto[I] menyatakan secara umum dapat dikatakan media mempunyai kegunaan, antara lain :

I. Memperjelas pesan agar tidak terlalu verbalistis

2. Mengatasi keterbatasan ruang, waktu, tenaga dan daya indra

3. Menimbulkan gairah belajar, interaksi lebih langsung murid dengan sumber belajar

4. Memungkinkan anak belajar mandiri sesuai dengan bakat dan kemampuan visual, auditori dan kinestetiknya.

5. Pemilihan media yang tepat akan memudahkan proses penyerapan materi pembelajaran oleh peserta didik, karena mereka dapat mengkonstruksi sendiri materi yang dipelajari.

Sesuai kurikulum tingkat satuan pendidikan Sekolah Menengah Pertama kelas IX terdapat materi sumber tegangan. Untuk menyampaikan materi sumber tegangan tidak cukup hanya penjelasan secara konvesional saja, diperlukan suatu inovasi media yang dapat digunakan langsung oleh peserta didik sehingga mereka bisa terlibat aktif dalam proses pembelajaran yang pada akhirnya konsep yang diperoleh bisa tertanam kuat dipikiran mereka.

Elemen volta merupakan sumber tegangan yang memanfaatkan dua elektroda yakni, tembaga $(\mathrm{Cu})$ sebagai elektroda positif dan seng ( $\mathrm{Zn}$ ) sebagai elektroda negatif dan memanfaatkan larutan elektrolit yang bersifat asam $\left(\mathrm{H}_{2} \mathrm{SO}_{4}\right)$. Lempeng tembaga memiliki potensial tinggi, sedangkan lempeng seng memiliki potensial rendah. Jika kedua lempeng logam itu dihubungkan melalui lampu, lampu akan menyala. Hal ini membuktikan adanya arus listrik yang mengalir pada lampu. Ketika lampu menyala, larutan elektrolit akan bereaksi dengan logam tembaga maupun seng sehingga menghasilkan sejumlah elektron yang mengalir dari seng menuju tembaga. Adapun, reaksi kimia pada elemen Volta adalah sebagai berikut:

Pada larutan elektrolit terjadi reaksi

$$
\mathrm{H}_{2} \mathrm{SO}_{4} \rightarrow 2 \mathrm{H}^{+}+\mathrm{SO}_{4}{ }^{2-}
$$

Pada kutub positif terjadi reaksi

$$
\mathrm{Cu}+2 \mathrm{H}^{+} \rightarrow \text { polarisasi } \mathrm{H}_{2}
$$

Pada kutub negatif terjadi reaksi

$$
\mathrm{Zn}+\mathrm{SO}_{4} \rightarrow \mathrm{ZnSO}_{4}+2 e
$$

Reaksi kimia pada elemen Volta akan menghasilkan gelembung-gelembung gas hidrogen $\left(\mathrm{H}_{2}\right)$. Gas hidrogen tidak dapat bereaksi dengan tembaga, sehingga gas hidrogen hanya menempel dan menutupi lempeng tembaga yang bersifat isolator listrik. Hal ini menyebabkan terhalangnya aliran elektron dari seng menuju tembaga maupun arus listrik dari tembaga menuju seng. Peristiwa tertutupnya lempeng tembaga oleh gelembung-gelembung gas hidrogen disebut polarisasi. Adanya polarisasi gas hidrogen pada lempeng tembaga menyebabkan elemen Volta mampu mengalirkan arus listrik hanya sebentar.

Salah satu media yang dapat dikembangkan untuk meningkatkan keaktifan siswa adalah penggunaan jeruk sebagai pengganti elektrolit pada elemen volta. Jeruk dipilih sebagai elektrolit pada sumber tegangan karena asam sitrat yang terkandug dalam jeruk memiliki $\mathrm{pH}$ yang cukup rendah.

Para peneliti sifat listrik dari bahan sejak dulu kala mengetahui bahwa kemampuan menghantar aliran listrik tidak terbatas pada logam. Cairan air murni adalah penghantar aliran listrik yang buruk. Penambahan zat terlarut tertentu ke dalam air menyebabkan larutan berair tersebut menjadi penghantar listrik yang baik [3]. Asam sitrat yang terkandung didalam jeruk/lemon dapat dijadikan zat terlarut dan mampu mengantarkan arus listrik. Lemon/jeruk mengandung asam yang tinggi, sehingga apabila terjadi reaksi antara asam yang berasal dari buah dengan lempengan-lempengan maka akan menyebabkan energi listrik [4][5]

Di samping jeruk memiliki tingkat keasaman $(\mathrm{pH})$ yang tinggi tingkat keasamannya juga bervariasi, sehingga pada pengembangan media ini peserta didik di ajak untuk mengamati bagaimana pengaruh tingkat keasaman $(\mathrm{pH})$ jeruk terhadap lamanya waktu polarisasi. Polarisasi adalah peristiwa tertutupnya elektroda elemen oleh hasil reaksi yang mengendap pada elektroda tersebut.[6]. Dengan kata lain proses polarisasi sempurna terjadi ketika arus listrik sudah tidak mengalir dalam rangkaian ditunjukkan dengan kembalinya jarum amperemeter ke titik nol.

\section{Metode Penelitian/Eksperimen}

Penelitian yang dilakukan menggunakan studi literatur yang dipadukan dengan eksperimen. Eksperimen dilakukan dengan menggunakan alat dan bahan sebagai berikut :

\section{Alat dan Bahan}

I. Buah Jeruk

2. Lempeng tembaga $(\mathrm{Cu})$ 
3. Lempeng seng $(\mathrm{Zn})$

4. Amperemeter

5. Kabel

6. Stopwatch

7. Indikator universal

\section{Prosedur Eksperimen}

Eksperimen dilakukan mengikuti langkah-langkah sebagai berikut :

I. Jeruk diambil ekstraknya kemudian dilarutkan dalam air

2. Larutan jeruk diukur tingkat keasamannya dengan menggunakan indikator universal

3. Masukkan elektroda ke dalam larutan jeruk

4. Catat lamanya waktu aru mengalir dalam rangkaian.

5. Ulangi langkah I-4 untuk jenis jeruk yang memiliki keasaman yang berbeda.

\section{Hasil Penelitian dan Pembahasan}

Dari hasil kegiatan eksperimen, diperoleh data sebagai berikut :

Tabel I. Nilai PH larutan dan waktu polarisasi untuk volume $100 \mathrm{ml}$

\begin{tabular}{cccc}
\hline No & $\begin{array}{c}\text { Elektrolit } \\
\text { (ekstrak jeruk) }\end{array}$ & Nilai pH & $\begin{array}{r}\text { Waktu } \\
\text { (sekon) }\end{array}$ \\
\hline \hline I & Larutan I & 2 & 3,56 \\
2 & Larutan 2 & 3 & 2,02 \\
3 & Larutan 3 & 4 & I,I6 \\
\hline
\end{tabular}

Tabel 2. Nilai PH larutan dan waktu polarisasi untuk volume $200 \mathrm{ml}$

\begin{tabular}{cccc}
\hline No & $\begin{array}{c}\text { Elektrolit } \\
\text { (ekstrak jeruk) }\end{array}$ & Nilai pH & $\begin{array}{c}\text { Waktu } \\
\text { (sekon) }\end{array}$ \\
\hline I & Larutan I & 2 & 5,52 \\
2 & Larutan 2 & 3 & 3,53 \\
3 & Larutan 3 & 4 & 3,07 \\
\hline
\end{tabular}

Dari hasil pengamatan diketahui bahwa buah jeruk dapat berperan sebagai elektrolit, hal ini dibuktikan pada saat lempeng seng sebagai elektroda negatif dan lempeng tembaga sebagai elektroda positif dimasukkan dalam ekstrak jeruk tampak penyimpangan jarum amperemeter. Ketika pelat seng dimasukkan ke dalam larutan jeruk, ion seng mulai terurai dan masuk kedalam elektrolit dengan meninggalkan elektron di dalam pelat seng. Selanjutnya elektron akan mengalir dari pelat seng ke plat tembaga dan menghasilkan arus listrik. Pada plat tembaga elektron akan bergabung dengan ion hidrogen asam menghasilkan hidrogen $\left(\mathrm{H}_{2}\right)$. Gas hidrogen tidak dapat bereaksi dengan tembaga, sehingga hanya menempel dan menutupi lempeng tembaga yang bersifat isolator listrik. Hal inilah yang menyebabkan terhalangnya aliran elektron dari seng menuju tembaga maupun aliran arus listrik dari tembaga menuju seng. Peristiwa tertutupnya lempeng tembaga oleh gelembung-gelembung gas hidrogen inilah yang disebut polarisasi.

Untuk ekstrak jeruk yang memiliki nilai $\mathrm{pH}$ berbeda ternyata dapat menghantarkan arus listrik yang berbeda pula. Dari hasil percobaan diperoleh data semakin rendah nilai keasaman $(\mathrm{pH})$ maka kemampuan menghantarkan arus listrik lebih lama, dengan kata lain proses polarisasinya memerlukan waktu yang relatif lama. Hal ini terjadi karena semakin asam ( $\mathrm{pH}$ rendah) jumlah ion $\mathrm{H}^{+}$ juga semakin banyak sehingga kemampuan melakukan proses reaksi kimia menjadi lebih lama. Reaksi kimia yang terjadi disekitar lempeng $\mathrm{Cu}$ ditunjukkan dengan terbentuknya gelembung-gelembung gas yang secara aktif masih bergerak. Selama gelembung masih aktif menunjukkan masih terjadi reaksi kimia dan selama itu pula arus listrik masih mengalir. Dalam jangka waktu tertentu gelembung gas menjadi stabil, tidak bereaksi lagi dan menempel pada lempeng $\mathrm{Cu}$ (terjadi proses polarisasi). Pada larutan yang $\mathrm{pH}$ nya diturunkan (larutan asam) maka akan menaikkan konsentrasi ion hidrogen $\mathrm{H}^{+}$. Ion-ion ini dapat bereaksi dengan ion $\mathrm{OH}^{-}$yang terbentuk pada katoda dan memberikan efek depolarisasi padanya[7]. Dengan adanya efek depolarisasi inilah yang menyebabkan proses polarisasi pada lempeng $\mathrm{Cu}$ menjadi lebih lama sehingga arus listri yang mengalir menjadi lebih lama pula.

Dengan menggunakan media pembelajaran yang berupa jeruk sebagai pengganti larutan elektrolit pada elemen volta akan memberikan makna yang lebih dalam bagi peserta didik dalam megikuti kegiatan pembelajaran. Peserta didik menjadi lebih tertarik untuk belajar IPA, karena dengan pemanfaatan media yang sederhana dan tersedia disekitarnya, pemahaman terhadap materi lebih dalam dan tertanam kuat.

\section{Kesimpulan}

Media pembelajaran dapat difungsikan untuk memaksimalkan pemahaman konsep peserta didik terhadap suatu konsep pembelajaran. Hal ini terjadi karena peserta didik mengalami sendiri, sehingga prinsip konstruktivisme dapat menancapkan lebih kuat materi yang dipelajari. Salah satu media yang dapat dikembangkan pada materi sumber tegangan khususnya elemen volta adalah jeruk sebagi pengganti larutan elektrolit $\mathrm{H}_{2} \mathrm{SO}_{4}$. Jeruk memiliki tingkat keasaman yang cukup bervariasi, sehingga dari hasil percobaan diketahui bahwa tingkat keasaman $(\mathrm{pH})$ jeruk mempengaruhi lamanya waktu terjadinya polarisasi. Semakin rendah $\mathrm{PH}$ (asam kuat) maka waktu polarisasinya semakin lama, sebaliknya semakin tinggi tinggi $\mathrm{pH}$ (asam lemah). Semakin cepat terjadi polarisasi. Hal ini terkait dengan 
semakin asam larutan ( $\mathrm{pH}$ rendah) maka konsentarsi ion $\mathrm{H}^{+}$bertambah dan ion-ion ini bisa bereaksi dengan ion $\mathrm{OH}^{-}$yang terbentuk pada katoda dan memberikan efek depolarisasi.

\section{Kepustakaan}

[I] Daryanto, Media Pembelajaran, Yogyakarta Gava Media, 2013

[2] Anitah, Sri, Media Pembelajaran, Surakarta.Panitia Sertifikasi Guru Rayon I3 FKIP UNS Surakarta.2009

[3] Petrucci H Ralph, General Chemistry (Terjemahan).Jakarta Erlangga.1987 (Penerjemah: Achmadi, Suminar)

[4] Ulya.S.A, Sutikno, Masturi, Pengaruh buah lemon sebagai media pembelajaran listrik dinamis terhadap kondisi stress belajar siswa.

[5] Chang Raymond, General Chemistry (terjemahan), Jakarta. Erlangga 2004 (Penerjemah Departemen Kimia ITB)

[6] Sudarjo.N, Suryono.I, Ensiklopedia IPA, Jakarta Lentera Abadi.2009

[7] Agus T. Sutjipto. F.Lahagu, dan B. Irianto, Perilaku korosi pelet $\mathrm{UO}_{2}$ dalam larutan korosif dengan teknik elektrokimia, Prosiding pertemuan dan presentasi ilmiah PPNY-BATAN Yogyakarta, Buku II, Yogyakarta, April I995, hal. 45-49. 